\title{
Seleksi Calon Pejantan dan Induk Sapi Madura Berdasarkan Nilai Pemuliaan Berat Lahir dan Sapih
}

\author{
Bull and Heifer Selection Based on Birth and Weaning Weight \\ Breeding Value in Madura Cattle
}

\author{
Y. A.Tribudi ${ }^{1}$, P. W. Prihandini ${ }^{2}$, M. I. Rahaddiansyah ${ }^{3}$, dan S. Anitasari ${ }^{4}$ \\ ${ }^{1}$ Program Studi Peternakan Fakultas Pertanian Universitas Tanjungpura \\ ${ }^{2}$ Loka Penelitian Sapi Potong Grati Pasuruan Jawa Timur \\ ${ }^{3}$ UPT Pembibitan Ternak dan Kesehatan Hewan Madura \\ ${ }^{4}$ Dinas Peternakan Provinsi Jawa Timur \\ Corresponding e-mail: yuliariftribudi@gmail.com
}

\begin{abstract}
Research on sire and heifer selection based on breeding value of birth and weaning weight Madura in Animal Breeding and Health Technical Unit of Pamekasan. Data consisted of production and population records collected from 2016 to 2019. Total cattle that used to breeding value of birth and weaning weight were 61 heads of cattle (18 bulls and 43 heifers) which then were corrected for estimating heritability based on paternal half-sib correlation. The results showed that the heritability of birth and weaning weight of Madura cattle respectively $0.41 \pm 0.37$ and $00.53 \pm 0.45$. Breeding values rank Madura bulls on birth and weaning weight was obtained by bulls number 20/911 (BV: $1.90 \mathrm{~kg}$ ) and 30/927 (BV: $16.06 \mathrm{~kg}$ ) and the highest breeding value of birth weight were on Madura cattle heifer number 10/680 (BV: $2.28 \mathrm{~kg}$ ) and weaning weight of heifer number 20/395 (BV: $16.48 \mathrm{~kg}$ ).
\end{abstract}

Keywords: birth weight, breeding value, Madura cattle, weaning weight

\begin{abstract}
ABSTRAK
Penelitian bertujuan untuk seleksi calon pejantan dan induk sapi Madura berdasarkan nilai pemuliaan berat lahir dan sapih di UPT Pembibitan Ternak dan Kesehatan Hewan Sapi Madura Pemekasan. Materi yang digunakan terdiri dari catatan produksi dan populasi sapi Madura tahun 2016 sampai 2019. Jumlah sapi Madura yang digunakan untuk mengestimasi nilai pemuliaan berat lahir dan sapih adalah 61 ekor (18 ekor calon pejantan dan 43 ekor calon induk) yang selanjutnya dilakukan koreksi untuk estimasi heritabilitas berdasarkan saudara tiri (paternal half sib correlation). Hasil penelitian menunjukkan nilai heritabilitas berat lahir dan berat sapih pada sapi Madura masing-masing adalah $0,41 \pm 0,37$ dan $00,53 \pm 0,45$. Rangking nilai pemuliaan calon pejantan sapi Madura berdasarkan berat lahir dan sapih tertinggi diperoleh pejantan no 20/911 (NP: 1,90 kg) dan 30/927 (NP: $16,06 \mathrm{~kg}$ ) sedangkan pada calon induk diduduki oleh ternak no 10/680 (NP: 2,28 kg) dan 20/395 (NP: 16,48 kg).
\end{abstract}

Kata kunci: berat lahir, berat sapih, nilai pemuliaan, sapi Madura

\section{PENDAHULUAN}

Sapi Madura merupakan salah satu sumber daya genetik Indonesia sapi lokal yang dikembangkan untuk memenuhi kebutuhan protein hewani. Keunggulan yang dimiliki sapi lokal antara lain tahan terhadap cuaca yang ekstrim, pakan yang jelek dan serangan caplak. Sapi Madura merupakan salah satu sapi lokal yang banyak dikembangkan di Jawa Timur. Populasi sapi Madura pada tahun 2019 tercatat mencapai 1.004.226 ekor di kabupaten Sampang, Bangkalan, Pamekasan dan Sumenep (Dinas Peternakan Jawa Timur, 2019) atau sekitar 5,8 persen dari populasi sapi nasional.
Unit Pelaksana Teknis (UPT) Pembibitan Ternak dan Kesehatan Hewan Sapi Madura Pamekasan sebagai sumber bibit penghasil sapi Madura unggul dengan menerapkan teknik-teknik pemuliaan dan pemurnian sapi Madura dimana populasi dan produktivitasnya terus ditingkatkan guna memenuhi kebutuhan peternak. Kegiatan seleksi dapat dilakukan dengan memperhatikan penampilan fenotipik ternak dan mempertimbangkan faktor lingkungan yang mempengaruhi penampilan fenotipiknya untuk mendapatkan ternak unggul (Nurgiartiningsih, 2011). Evaluasi mutu genetik ternak dalam program pemuliaan dapat dilakukan dengan estimasi nilai pemuliaan individu sebagai dasar

1 | Seleksi calon pejantan dan induk sapi Madura Berdasarkan nilai pemuliaan...(Tribudi et al., 2021) 
pelaksanaan seleksi. Nilai pemuliaan merupakan pencerminan potensi genetik yang dimiliki seekor ternak untuk sifat tertentu yang diberikan secara relatif atas kedudukannya di dalam suatu populasi.

Seleksi dapat didasarkan atas nilai pemuliaannya, yang merupakan keunggulan individu terhadap rataan kelompoknya apabila antar individu terjadi perkawinan secara acak (Prihandini et al., 2012). Bourdon (1997) menjelaskan apabila nilai pemuliaan masingmasing ternak diketahui dengan pasti, maka penentuan peringkat keunggulan ternak dalam populasi dapat diketahui dengan mudah. Nilai pemuliaan individu sangat menentukan performans keturunannya nantinya, oleh karenanya nilai pemuliaan dapat menjadi dasar dalam melakukan seleksi dengan memilih ternak yang nilai pemuliaannya paling tinggi untuk dijadikan tetua. Potensi genetik dapat tercermin dari beberapa sifat produksi, diantaranya adalah berat lahir dan berat sapih. Untuk memperoleh induk dan pejantan yang berkualitas tinggi terlebih dahulu dilakukan seleksi pada calon pejantan dan calon induk berdasarkan pada nilai pemuliaan (NP) masing-masing individu berdasarkan berat lahir dan sapih sehingga diharapkan dapat membantu UPT Pembibitan Ternak dan Kesehatan Hewan Sapi Madura Pemekasan dalam melakukan replacement sapi Madura.

\section{MATERI DAN METODE}

Materi yang digunakan berupa data catatan produksi sapi Madura yang dipelihara di UPT Pembibitan Ternak dan Kesehatan Hewan Sapi Madura Pemekasan dari tahun 2016 sampai 2019. Data yang diambil meliputi data berat badan, catatan kelahiran, dan silsilah ternak dengan jumlah sapi Madura yang dianalisis sebesar 61 ekor (18 ekor jantan dan 43 ekor betina). Data yang diperoleh dikoreksi sebelum dihitung nilai heritabilitas dan nilai pemuliaan dengan beberapa tahapan antara lain:

Berat lahir adalah berat pedet yang dihasilkan dari penimbangan pada waktu pedet dilahirkan atau maksimal 3 (tiga) hari setelah pedet dilahirkan (Direktorat Jenderal Peternakan, 2007).

Data berat sapih disesuaikan pada umur 205 hari, diasumsikan sapi Madura ditimbang pada umur yang seragam yaitu 205 hari. Rumus yang digunakan adalah sebagai berikut (Hardjosubroto, 1994):

$$
\mathrm{BS}_{205}=\left(\frac{\mathrm{BB}-\mathrm{BL}}{\mathrm{Umur}} \times 205+\mathrm{BL}\right)
$$

Keterangan:

$\mathrm{BS}_{205}$ : berat sapih terkoreksi pada umur 205 hari $(\mathrm{kg})$

BB : berat pada saat ditimbang pada waktu penyapihan $(\mathrm{kg})$

BL : berat lahir $(\mathrm{kg})$

Umur : umur pada saat penyapihan (hari)

Komponen ragam nilai heritabilitas berat lahir dan sapih dihitung menggunakan Restricted Maximum Likelihood (REML) pola Linear Mixed Model dengan pengaruh tetap adalah tahun dan jenis kelamin sedangkan pengaruh acak adalah pejantan (Knight, 2008) kemudian nilai heritabilitas dihitung menggunakan metode paternal half sib correlation (Becker, 1975). Sementara itu, nilai pemuliaan calon pejantan dan calon induk dihitung berdasarkan performans individu tersebut yang dinyatakan dalam rumus (Hardjosubroto, 1994).

$$
N P=h^{2}(\bar{P}-\overline{\bar{P}})
$$

Keterangan:

$\mathrm{NP} \quad=$ Nilai Pemuliaan

$\mathrm{h}^{2} \quad=$ Nilai heritabilitas

$\overline{\mathrm{P}} \quad=$ Performans individu

$\overline{\overline{\mathrm{P}}} \quad$ = Rata-rata performans populasi dimana individu berada

Peringkat keunggulan nilai pemuliaan berdasarkan berat lahir dan sapih pada sapi Madura ditentukan menggunakan uji rank correlation.

\section{HASIL DAN PEMBAHASAN}

Rataan berat lahir dan sapih sapi Madura di UPT Pembibitan Ternak dan Kesehatan Hewan Sapi Madura Pemekasan sebesar 16,89 $\pm 2,86 \mathrm{~kg}$ dan $82,95 \pm 15,09 \mathrm{~kg}$ (Tabel 1) lebih tinggi dari laporan Karnaen (2004) sebesar 14,51 kg tetapi lebih rendah hasil penelitian Tribudi et al. (2019); Nurgiartiningsih (2011); Sulistiyoningtyas et al. (2017). Perbedaan berat lahir dan sapih sapi Madura dengan penelitian yang lain diduga karena, waktu, lokasi dan populasi penelitian yang berbeda serta pakan dan pemeliharaan (Zhou et al., 2003; Haile et al., 2009). 
Tabel 1. Rataan berat badan, koefisen keragaman dan estimasi heritabilitas berat lahir dan sapih sapi Madura di UPT Pembibitan dan Kesehatan Hewan Sapi Madura Pemekasan

\begin{tabular}{cccc}
\hline Parameter & Berat badan $(\mathrm{kg})$ & KK $(\%)$ & Heritabilitas \\
\hline Berat lahir & $16,89 \pm 2,86$ & 16,96 & $0,41 \pm 0,37$ \\
Berat sapih & $82,95 \pm 15,09$ & 18,19 & $0,53 \pm 0,45$ \\
\hline
\end{tabular}

Tabel 1 menunjukkan bahwa koefisien keragaman berat lahir dan sapih sapi Madura dalam kategori sedang yaitu antara 16\%-19\% (Harsojuwono et al., 2011). Hal ini berarti data sapi Madura di UPT Pembibitan Ternak dan Kesehatan Hewan Sapi Madura Pemekasan termasuk dalam kategori heterogen, seleksi ternak yang heterogen maka respon yang akan diperoleh lebih tinggi dibandingkan seleksi pada ternak yang homogen

Estimasi heritabilitas berat lahir dan sapih pada sapi Madura (Tabel 1) yang dihasilkan termasuk dalam kategori tinggi (Boligon et al., 2016). Hasil estimasi heritabilitas berat lahir sapi Madura lebih rendah dari penelitian Tribudi dan Nurgiartiningsih (2014) sebesar 0,31 $\pm 0,19$, sedangkan nilai heritabilitas berat sapih lebih rendah daripada penelitian Karnaen (2004) dan
Tribudi et al. (2019) sebesar 0,87 $\pm 0,45$ dan $0,64 \pm 0,22$. Perbedaan nilai heritabilitas dengan beberapa penelitian sebelumya disebabkan karena perbedaan jumlah populasi dan waktu estimasi (MacNeil et al., 2000). Tingginya nilai heritabilitas menunjukkan bahwa perbedaan penampilan pada karakter tersebut lebih dipengaruhi oleh genetik dan sedikit oleh lingkungan (Supriyantono et al., 2018). Nilai heritabilitas yang diperoleh kurang handal apabila digunakan sebagai standar seleksi karena nilai simpangan baku yang mendekati nilai heritabilitasnya namun demikian seleksi berdasarkan berat lahir dan sapih pada sapi Madura tetap dapat dilakukan karena sapi Madura belum pernah diseleksi secara intensif dengan menggunakan parameter genetik tetapi berdasarkan performans kualitatif.

Tabel 2. Peringkat nilai pemuliaan (NP) calon pejantan berdasarkan berat lahir dan sapih pada sapi Madura di UPT Pembibitan dan Kesehatan Hewan Sapi Madura Pemekasan

\begin{tabular}{ccc|cccc}
\hline \multirow{2}{*}{ Kode Sapi } & \multicolumn{2}{|c|}{ Berat badan $(\mathrm{kg})$} & \multicolumn{4}{c}{ Nilai Pemuliaan (NP) } \\
\cline { 2 - 6 } & Berat lahir & Berat sapih & Berat lahir & rank & Berat sapih & rank \\
\hline $30 / 919$ & 19 & 95 & 0.43 & 7 & 7.58 & 4 \\
$30 / 924$ & 16 & 80 & -0.80 & 12 & -0.37 & 9 \\
$40 / 925$ & 15.8 & 63 & -0.89 & 13 & -9.38 & 16 \\
$30 / 927$ & 18 & 111 & 0.02 & 9 & 16.06 & 1 \\
$20 / 933$ & 12.8 & 94 & -2.12 & 18 & 7.05 & 5 \\
$30 / 922$ & 18 & 101.5 & 0.02 & 10 & 11.03 & 2 \\
$10 / 939$ & 18.2 & 53.5 & 0.10 & 8 & -14.41 & 18 \\
$10 / 923$ & 14.05 & 74.5 & -1.60 & 17 & -3.28 & 14 \\
$30 / 915$ & 20.5 & 81 & 1.04 & 6 & 0.16 & 8 \\
$10 / 106$ & 21.5 & 76 & 1.45 & 3 & -2.49 & 10 \\
$20 / 118$ & 15.6 & 85 & -0.97 & 15 & 2.28 & 6 \\
$40 / 384$ & 15.8 & 76 & -0.89 & 14 & -2.49 & 11 \\
$30 / 916$ & 22.4 & 84.69 & 1.82 & 2 & 2.12 & 7 \\
$20 / 911$ & 22.6 & 75.3 & 1.90 & 1 & -2.86 & 13 \\
$10 / 926$ & 21 & 60.9 & 1.25 & 5 & -10.49 & 17 \\
$20 / 391$ & 16.5 & 99 & -0.60 & 11 & 9.70 & 3 \\
$20 / 394$ & 14.1 & 66 & -1.58 & 16 & -7.79 & 15 \\
$10 / 106$ & 21.5 & 76 & 1.45 & 4 & -2.49 & 12 \\
\hline
\end{tabular}


Evaluasi potensi genetik calon pejantan dan induk merupakan salah satu program pemuliaan yang sangat penting dalam seleksi ternak. Seleksi berdasarkan potensi genetik akan mampu meningkatkan efektivitas seleksi sehingga dapat meningkatkan kemajuan genetik akibat seleksi. Potensi genetik calon pejantan dan induk dapat diprediksi dari performans yang dapat diukur. Bobot lahir dan sapih merupakan dua variabel penting dalam menduga kemampuan berproduksi individu ternak. Peringkat nilai pemuliaan calon pejantan dan induk sapi Madura berdasarkan berat lahir dan sapih disajikan pada Tabel 2 dan 3.

Berdasarkan hasil perhitungan dari 18 calon pejantan yang memiliki performans diatas rataan populasi atau memiliki nilai pemuliaan positif yaitu sebesar 55,55\% (10 ekor calon pejantan) untuk berat lahir dengan rataan populasi sebesar 17,96 kg dan 50\% (9 ekor calon pejantan) untuk berat sapih dengan rataan populasi sebesar $80,69 \mathrm{~kg}$. Calon pejantan yang memiliki nilai pemuliaan negatif menunjukkan bahwa performansnya dibawah rataan populasi, dalam seleksi calon pejantan yang memiliki nilai negatif akan disingkirkan. Rangking nilai pemuliaan calon pejantan sapi Madura menurut Hardjosubroto (1994) maka ternak yang memiliki berat lahir dan sapih tertinggi diperoleh calon pejantan no 20/911 dan 30/927. Hasil ini sesuai penelitian Patmawati et al. (2013) yang melaporkan hasil uji performans pada sapi Bali di BPTU Sapi Bali berdasarkan ukuran tubuh menunjukkan terdapat perbedaan peringkat pejantan sapi Bali yang diukur berdasarkan berat badan dan ukuran tubuh

Apabila nilai pemuliaan masing-masing individu calon pejantan diketahui pasti, maka penentuan peringkat keunggulan tenak dalam populasi dapat mudah diketahui dengan mudah. Pejantan yang memiliki nilai pemuliaan terbaik dapat diseleksi untuk dipilih sebagai calon pejantan unggul agar dapat mengawini ternak betina, sehingga diharapkan keturunannya dapat memiliki performans produksi dan reproduksi yang baik seperti tetuanya (Baharun et al., 2017). Sedangkan pejantan yang memiliki nilai keunggulan genetik rendah dapat diculling karena dikhawatirkan bila digunakan untuk mengawini sapi betina maka anak keturunannya akan memiliki produktivitas rendah seperti tetuanya (Putra et al., 2015). Oleh karena itu, nilai pemuliaan dapat digunakan sebagai salah satu tolak ukur seleksi untuk pemilihan calon pejantan unggul.

Pada Tabel 3 diketahui bahwa nilai pemuliaan tertinggi berat lahir dan sapih calon induk sapi Madura tertinggi diduduki oleh ternak no 10/680 dan 20/395 masing-masing sebesar $2,28 \mathrm{~kg}$ dan $16,48 \mathrm{~kg}$ berdasarkan prosedur Hardjosubroto (1994). Hasil perhitungan 43 calon induk yang memiliki performans diatas rata-rata populasi (rata-rata berat lahir dan sapih calon induk sapi Madura masing-masing 16,43 kg dan $83,90 \mathrm{~kg}$ ) atau memiliki nilai pemuliaan positif yaitu sebesar 53,48\% (23 ekor calon induk) untuk berat lahir dan 51,16\% (22 ekor calon induk) untuk berat sapih. Ternak yang memiliki nilai pemuliaan tinggi dan positif sebaiknya digunakan sebagai calon induk pada generasi berikutnya. Ternak yang mempunyai nilai pemuliaan lebih besar dari populasi akan lebih baik jika dijadikan tertua bila dibandingkan dengan ternak yang memiliki nilai pemuliaan rendah. Individu dengan nilai pemuliaan yang tinggi akan menunjukkan kemampuannya untuk mewariskan potensi genetik pada keturunannya dan mengulang produksinya.

Hasil estimasi nilai pemuliaan berat lahir dan sapih pada 18 calon pejantan (Tabel 2) dan 43 calon induk (Tabel 3) pada sapi Madura menunjukkan bahwa sebagian besar calon pejantan dan induk sapi Madura memiliki peringkat berbeda yang disebabkan pengaruh lingkungan yang berbeda pada berat lahir dan sapih. Hasil uji rank correlation menunjukan terdapat korelasi yang berbeda nyata $(\mathrm{P}<0,05)$ antara peringkat keunggulan calon pejantan dan induk berdasarkan nilai pemuliaan bobot lahir dengan sapih. Artinya, ada hubungan yang erat antara peringkat keunggulan ternak berdasarkan nilai pemuliaan berat lahir dengan sapih pada sapi Madura.

UPT Pembibitan Ternak dan Kesehatan Hewan Sapi Madura Pemekasan diharapkan dapat melakukan seleksi calon pejantan dan induk berdasarkan berat sapih karena berat sapih berkorelasi positif dengan berat setahun. Pedet yang mempunyai berat sapih tinggi akan tumbuh lebih cepat sehingga mencapai berat setahun yang lebih tinggi. Sementara itu jika didasarkan berat lahir kemungkinan terjadinya kesukaran melahirkan (dystochia) selain itu seleksi pada berat lahir belum bisa menggambarkan kemampuan mengasuh anak (mothering ability) dari seekor induk (Putra et al., 2014). 
Tabel 3. Peringkat nilai pemuliaan (NP) calon induk berdasarkan berat lahir dan sapih pada sapi Madura di UPT Pembibitan dan Kesehatan Hewan Sapi Madura Pemekasan

\begin{tabular}{|c|c|c|c|c|c|c|}
\hline \multirow{2}{*}{ Kode Sapi } & \multicolumn{2}{|c|}{ Berat badan (kg) } & \multicolumn{4}{|c|}{ Nilai Pemuliaan (NP) } \\
\hline & Berat lahir & Berat sapih & Berat lahir & rank & Berat sapih & rank \\
\hline $10 / 672$ & 12 & 110.73 & -1.82 & 41 & 14.22 & 3 \\
\hline $10 / 674$ & 15.5 & 111.50 & -0.38 & 30 & 14.63 & 2 \\
\hline $10 / 673$ & 16 & 71.81 & -0.18 & 24 & -6.41 & 31 \\
\hline $10 / 678$ & 20 & 106.32 & 1.46 & 4 & 11.88 & 4 \\
\hline $10 / 680$ & 22 & 102.99 & 2.28 & 1 & 10.12 & 8 \\
\hline $10 / 661$ & 13 & 88.30 & -1.41 & 35 & 2.33 & 19 \\
\hline $10 / 659$ & 13 & 61.11 & -1.41 & 36 & -12.08 & 43 \\
\hline $10 / 690$ & 18 & 66.31 & 0.64 & 10 & -9.32 & 36 \\
\hline $10 / 664$ & 17 & 78.70 & 0.23 & 18 & -2.76 & 26 \\
\hline $10 / 689$ & 17 & 63.58 & 0.23 & 19 & -10.77 & 41 \\
\hline $10 / 669$ & 16 & 73.12 & -0.18 & 25 & -5.72 & 30 \\
\hline $10 / 691$ & 21 & 84.69 & 1.87 & 3 & 0.42 & 21 \\
\hline $10 / 667$ & 17 & 69.44 & 0.23 & 20 & -7.66 & 35 \\
\hline $10 / 692$ & 12 & 63.58 & -1.82 & 42 & -10.77 & 42 \\
\hline 20/919 & 13 & 75.95 & -1.41 & 37 & -4.21 & 27 \\
\hline $10 / 915$ & 16 & 65.59 & -0.18 & 26 & -9.71 & 37 \\
\hline 30/912 & 19 & 90.34 & 1.05 & 6 & 3.41 & 13 \\
\hline 20/914 & 17 & 95.00 & 0.23 & 21 & 5.88 & 9 \\
\hline $10 / 928$ & 13 & 92.22 & -1.41 & 38 & 4.41 & 12 \\
\hline $30 / 925$ & 14 & 89.48 & -1.00 & 34 & 2.96 & 15 \\
\hline 40/916 & 18 & 81 & 0.64 & 11 & -1.54 & 24 \\
\hline $30 / 923$ & 18 & 95 & 0.64 & 12 & 5.88 & 10 \\
\hline 20/918 & 12 & 105 & -1.82 & 43 & 11.18 & 5 \\
\hline $50 / 916$ & 17 & 80.5 & 0.23 & 22 & -1.80 & 25 \\
\hline 20/928 & 16.5 & 86 & 0.03 & 23 & 1.11 & 20 \\
\hline $10 / 943$ & 19.5 & 83.03 & 1.26 & 5 & -0.46 & 23 \\
\hline $10 / 940$ & 16 & 73.78 & -0.18 & 27 & -5.36 & 29 \\
\hline $10 / 380$ & 12.5 & 71 & -1.61 & 40 & -6.84 & 32 \\
\hline $10 / 396$ & 16 & 89 & -0.18 & 28 & 2.70 & 16 \\
\hline $30 / 387$ & 17.7 & 89 & 0.52 & 13 & 2.70 & 17 \\
\hline $20 / 382$ & 17.6 & 105 & 0.48 & 16 & 11.18 & 6 \\
\hline $10 / 116$ & 14.1 & 71 & -0.96 & 32 & -6.84 & 33 \\
\hline $20 / 396$ & 19 & 64 & 1.05 & 7 & -10.55 & 39 \\
\hline $30 / 392$ & 15.2 & 93 & -0.50 & 31 & 4.82 & 11 \\
\hline 20/919 & 13 & 75.95 & -1.41 & 39 & -4.21 & 28 \\
\hline $10 / 915$ & 16 & 65.59 & -0.18 & 29 & -9.71 & 38 \\
\hline $30 / 912$ & 19 & 90.34 & 1.05 & 8 & 3.41 & 14 \\
\hline $10 / 927$ & 22 & 84.69 & 2.28 & 2 & 0.42 & 22 \\
\hline $20 / 395$ & 17.7 & 115 & 0.52 & 14 & 16.48 & 1 \\
\hline $30 / 387$ & 17.7 & 89 & 0.52 & 15 & 2.70 & 18 \\
\hline $20 / 382$ & 17.6 & 105 & 0.48 & 17 & 11.18 & 7 \\
\hline $10 / 116$ & 14.1 & 71 & -0.96 & 33 & -6.84 & 34 \\
\hline $20 / 396$ & 19 & 64 & 1.05 & 9 & -10.55 & 40 \\
\hline
\end{tabular}

Nilai pemuliaan (breeding value) merupakan nilai keunggulan individu ternak sebagai kontributor gen-gen unggul untuk generasi yang akan datang. Nilai pemuliaan tidak dapat diukur secara langsung, namun dapat diperkirakan atau diprediksi dengan pendekatan Estimated Breeding Value (EBV). Seekor ternak yang mempunyai nilai pemuliaan diatas rata-rata kelompok, menunjukkan potensi keunggulan performans produksinya yang dapat diwariskan kepada anaknya. Ternak yang mempunyai nilai pemuliaan lebih besar akan lebih baik bila dijadikan sebagai bibit dibandingkan dengan ternak yang mempunyai nilai pemuliaan rendah 
(Putra et al., 2015). Semakin besar estimasi nilai pemuliaan pada seekor ternak menunjukan keunggulan potensi genetik ternak tersebut dari rata-rata populasi dimana ternak tersebut berada. Hasil perhitungan nilai pemuliaan yang tinggi dan positif yang diperoleh calon pejantan dan induk pada perhitungan ini dapat dijadikan referensi pemilihan bakalan calon pejantan dan induk untuk replacemet stock pejantan dan induk yang sudah tua di UPT Pembibitan Ternak dan Kesehatan Hewan Sapi Madura Pemekasan, karena calon pejantan dan induk yang telah teruji akan mempunyai produktivitas yang tinggi dalam menghasilkan keturunan yang unggul seperti tetuanya.

\section{KESIMPULAN}

Nilai pemuliaan berat lahir dan sapih dapat digunakan sebagai dasar seleksi pemilihan replacemet stock calon pejantan dan induk pada sapi Madura di UPT Pembibitan Ternak dan Kesehatan Hewan Sapi Madura Pemekasan dimana dari 18 ekor calon pejantan sapi Madura yang dievaluasi, diperoleh estimasi nilai pemuliaan bobot lahir diatas rata-rata kelompok sebanyak 55,55 persen (10 ekor calon pejantan) dan untuk berat sapih sebanyak 50 persen ( 9 ekor) sementara itu untuk calon induk dari 43 ekor diperoleh 53,48\% (23 ekor calon induk) untuk berat lahir dan 51,16\% (22 ekor calon induk) untuk berat sapih yang mempunyai nilai pemuliaan diatas rata-rata.

\section{DAFTAR PUSTAKA}

Baharun, A., H. L. L Belli dan T. M. Hine. 2017. Karakteristik Pejantan Muda Sapi Bali pada Peternakan Rakyat di Desa Merbaun Kabupaten Kupang. Jurnal Peternakan Nusantara 3 (1): 11-16.

Becker, W. A. 1992. Manual of Quantitative Genetics. Fifth Edition. Academic Enterprises, Pullman. Washington.

Boligon, A. A., I. S. Vicente and R. Z. Vaz. 2016 Principal component analysis of breeding values for growth and reproductive traits and genetic association with adult size in beef cattle. Journal Animal Science 94 (12): 5014-5022.

Bourdon, R. M. 1997. Understanding Animal Breeding. Prentice Hall, Inc. New Jersey.
Dinas Peternakan. 2019. Statistik Sapi Madura. Dinas Peternakan Provinsi Jawa Timur. Surabaya.

Direkorat Jenderal Peternakan. 2007. Petunjuk Teknis Uji Performans Sapi Potong Nasional. Kementerian Pertanian. Jakarta.

Haile, A., B.K Joshi., W. Ayalew., A. Tegeg and A. Singh. 2009. Genetic evaluation of Ethiopian Boran cattle and their crosses with Holstein Frisien in Central Ethiopia; reproductive traits. J Agric Sci. 147: 81-89.

Hardjosubroto, W. 1994. Aplikasi Pemuliaan Ternak di Lapang. Gramedia. Jakarta.

Harsojuwono, B. A., I.W. Arnata dan G.A.K.D. Puspawati. 2011. Rancangan Percobaan: Teori, Aplikasi SPSS dan Excel. Lintas Kata. Jakarta

Karnaen. 2004. Model Kurva Pertumbuhan Sapi Madura Betina dan Jantan dari Lahir sampai Umur Enam Bulan. Jurnal Ilmu Ternak 7 (1): 48-51.

Knight, E. 2008. Improved Iterative Scemes for REML estimation of Variance Parameters in Linear Mixed Models. School of Agriculture, Food and Wine. The University of Adelaide. Adelaide.

MacNeil, M. D., J. J Urick and G. Decoudu. 2000 Characteristics of line Hereford female resulting from selection by independent culling levels for below-average birth weight and high yearling weight or by mass selection for high yearling weight. J Anim Sci. 84: 2292-2298.

Nurgiartiningsih, V.M.A. 2011. Evaluasi Genetik Pejantan Boer Berdasarkan Performans Hasil Persilangannya Dengan Kambing Lokal. Jurnal Ternak Tropika 12 (1): 82-88.

Nurgiatiningih, V.M.A. 2011. Peta Potensi Genetik Sapi Madura Murni di Empat Kabupaten di Madura. Jurnal Ternak Tropika 12 (2): 23-32.

Patmawati, N.W., N.N. Trinayani., M. Siswanto., I.N. Wandita dan I.K. Puja. 2013. Seleksi awal pejantan sapi Bali berdasarkan catatan produksi. Jurnal Ilmu dan Kesehatan Hewan. 1 (1): 29-33.

Prihandini, P.W., L. Hakim dan V.M.A. Nurgiartiningsih. 2012. Seleksi Pejantan Berdasarkan Nilai Pemuliaan pada Sapi Peranakan Ongole (PO) di Loka Penelitian 
Sapi Potong Grati - Pasuruan. Jurnal Ternak Tropika 13 (1): 9-18.

Putra, W.P.B., Sumadi dan T. Hartatik. 2014. Estimasi Nilai Pemuliaan dan Most Probable Producing Ability Sifat Produksi Sapi Aceh Di Kecamatan Indrapuri Provinsi Aceh Buletin Peternakan 38 (1): 17.

Putra, W.P.B., Sumadi., T. Hartatik dan H. Saumar. 2015. Seleksi pada Sapi Aceh berdasarkan Metode Indeks Seleksi dan Nilai Pemuliaan. Jurnal Peternakan Sriwijaya 4 (1):1-10.

Putra, W.P.B., Sumadi., T. Hartatik dan H. Saumar. 2015. Seleksi Awal Calon Pejantan Sapi Aceh Berdasarkan Berat Badan. Jurnal Sain Peternakan Indonesia 10 (1): 7-12.

Supriyantono, A., I.T.W. Widayat and I. Sumpe. 2018. Potential of bali cattle: breeding value of bull on weaning weight, yearling weight and body weight gain. Int J Mol Biol Open Access 3 (5): 217-220.

Tribudi, Y.A dan V.M.A. Nurgiartiningsih. 2014. Estimasi heritabilitas sifat kuantitatif pada sapi Madura di Pulau Madura. Prosiding Seminar Nasional Peternakan: Teknologi Dan Agribisnis Peternakan Untuk Akselerasi Pemenuhan Pangan Hewani (Seri II), Purwokerto, 14 Juni 2014

Tribudi, Y.A., V.M.A. Nurgiartiningsih dan P.W. Prihandini. 2019. Pendugaan nilai heritabilitas sifat pertumbuhan pada Sapi Madura. Jurnal Ilmu-Ilmu Peternakan 29 (2): $15-157$.

Zhou, H.M., D. Allain., J.Q. Li., W.G Zhang and X.C. Yu. 2003. Effect of non-genetic factors on production traits of Inner Mongolia cashmere goats in China. Small Rumin Res. 47: 85-89. 